\title{
ARTIKELEN
}

\section{Verschillend organiseren, verschillend functioneren?}

\section{De invloed van de organisatie van Jeugd- (en Gezins)teams op het teamfunctioneren ${ }^{*}$}

\author{
Laura Nooteboom, Janna Eilander, Joris van der Voet, Ben Kuipers, Bram Steijn, \\ Robert Vermeiren \& Eva Mulder ${ }^{* *}$
}

\section{Inleiding}

Introductie en doelstelling

De gemeenten zijn sinds de transitie van de jeugdhulp op 1 januari 2015 zowel inhoudelijk als financieel verantwoordelijk voor de jeugdhulp in Nederland. De taken en verantwoordelijkheden van de gemeenten zijn verankerd in de nieuwe Jeugdwet (Eerste Kamer der Staten-Generaal 2013/14). Op basis van de wettelijke afspraken wordt op lokaal niveau invulling gegeven aan de nieuwe structuur. De organisatie van jeugdhulp kan per regio of gemeente verschillen, maar is overal gebaseerd op de transformatiedoelen die in de nieuwe Jeugdwet zijn geformuleerd (Rijksoverheid \& VNG, 2014). In de transformatiedoelen staat onder andere beschreven dat het belangrijk is om uit te gaan van de eigen regie en de eigen kracht van gezinnen, het sociaal netwerk in te zetten, tijdig juiste hulp op maat te bieden en samen te werken aan een integraal hulpaanbod (Eerste Kamer der Staten-Generaal 2013/14).

* De auteurs verklaren dat er geen sprake is van belangenverstrengeling. Zij hebben een gelijke bijdrage geleverd aan de totstandkoming van dit artikel.

** Laura Nooteboom is onderzoeker bij de Academische Werkplaats Gezin aan Zet, en promovenda bij Curium-LUMC het Academisch Centrum voor Kinder- en Jeugdpsychiatrie in Oegstgeest. Janna Eilander is onderzoeker bij de Academische Werkplaats Gezin aan Zet, bij Curium-LUMC, Academisch Centrum voor Kinder- en Jeugdpsychiatrie. Dr. Joris van der Voet is universitair docent aan het Instituut Bestuurskunde, faculteit Governance and Global Affairs van de Universiteit Leiden. Dr. Ben Kuipers is universitair hoofddocent aan het Instituut Bestuurskunde, faculteit Governance and Global Affairs van de Universiteit Leiden, en organisatieontwikkelaar en bestuurder bij Verbetervermogen in Amsterdam. Prof. dr. Bram Steijn is hoogleraar humanresourcesmanagement in de publieke sector, afdeling Bestuurskunde en Sociologie aan de Erasmus School of Social and Behavioral Sciences van de Erasmus Universiteit Rotterdam. Prof. dr. Robert Vermeiren is directeur patientenzorg en hoofd van de afdeling Onderzoek en Onderwijs bij Curium-LUMC, Academisch Centrum voor Kinder- en Jeugdpsychiatrie. Dr. Eva Mulder is projectleider bij de Academische Werkplaats Gezin aan Zet en Senior onderzoeker bij Curium-LUMC, Academisch Centrum voor Kinder- en Jeugdpsychiatrie. 
Sinds de transitie zijn in de meeste gemeenten wijkteams actief, ook wel Jeugd(en Gezins)teams genoemd (Arum \& Van den Enden, 2018). Het oprichten van deze multidisciplinaire teams moet helpen om de transformatiedoelen te bereiken, onder meer doordat deze teams op lokaal niveau laagdrempelig en vroegtijdig hulp bieden bij opvoed- en opgroeivragen en ze expliciet als doel hebben om de regie bij ouders en jongeren te laten (Eerste Kamer der Staten-Generaal 2013/14). De professionals uit de Jeugd- (en Gezins)teams verwijzen alleen door naar specialistische zorg wanneer dat nodig is en zijn een spin in het web in samenwerking met de ketenpartners, waaronder scholen, huisartsen en de jeugdgezondheidszorg (Basisdocument coöperatie Jeugd en Gezinsteams Holland Rijnland, 2015; Eilander e.a., 2017).

Hoewel op het moment van schrijven 88 procent van de Nederlandse gemeenten werkt met Jeugd- (en Gezins)teams, bestaan er tussen gemeenten veel verschillen in de manier waarop deze teams zijn georganiseerd (Arum \& Van den Enden, 2018). Zo zijn er verschillen in de samenstelling van de teams: in sommige gemeenten zijn de Jeugd- (en Gezins)teams samen met teams voor volwassenen onderdeel van integrale ' 0 tot 100'-teams, terwijl er in andere gemeenten specifieke teams zijn voor hulpverlening aan jeugd en volwassenen (Arum \& Van den Enden, 2018). Een ander verschil bestaat op het gebied van de aansturing van de teams. In sommige gemeenten zijn de Jeugd- (en Gezins)teams in sterke mate zelfsturend, terwijl de teams in andere gemeenten opereren onder leiding van een teamleider, teammanager of coördinator (Eilander e.a., 2017). De grote diversiteit tussen gemeenten lijkt te suggereren dat gemeenten bij het decentraliseren ieder voor zich hebben getracht het wiel uit te vinden om zo optimaal mogelijk aan te sluiten bij de lokale behoeften.

$\mathrm{Nu}$ de Jeugd- (en Gezins)teams in vrijwel alle gemeenten operationeel zijn, is het tijd om de onderlinge verschillen in de organisatie van de teams verder te bestuderen. Onderzoek naar teams in de jeugdhulpverlening bestaat nauwelijks, maar uit onderzoek naar teams in de managementwetenschappen weten we dat hoe hoger de kwaliteit van het teamfunctioneren, hoe hoger de kwaliteit van het primair proces (Kuipers \& Groeneveld, 2014; Evans \& Dion, 1999; Mesmer-Magnus \& DeChurch, 2009). Onderzoek in de zorg laat zien dat teamprocessen belangrijk zijn voor de kwaliteit van de dienstverlening (Poulton \& West, 1999). Uit onderzoek blijkt dat aspecten als onderlinge samenwerking of samenwerking met ketenpartners van invloed kunnen zijn op teamprestaties (Kuipers \& Groeneveld, 2014). Daarnaast kunnen verschillende vormen van leiderschap samenhangen met de effectiviteit van teams (Kozlowski \& Ilgen, 2006; Zaccara, Heinen \& Shuffler, 2009).

Onder andere in het kader van doorontwikkeling van de Jeugd- (en Gezins)teams wordt in veel gemeenten nagedacht over het verbeteren of veranderen van de wijze van organiseren van deze teams. Er is echter weinig inzicht in de gevolgen van verschillende manieren van organiseren voor het functioneren van de Jeugd(en Gezins)teams, terwijl er lokaal wel grote verschillen in de organisatie bestaan. In dit onderzoek worden Jeugd- (en Gezins)teams uit twee regio's met een zeer 
uiteenlopende wijze van organiseren met elkaar vergeleken. De uitkomsten van dit artikel kunnen richting geven aan beleidsmakers en jeugdhulporganisaties wat betreft het opzetten en doorontwikkelen van de Jeugd- (en Gezins)teams.

In dit artikel combineren we kwantitatieve en kwalitatieve data uit twee regiooverstijgende onderzoeken naar het intern functioneren van Jeugd- (en Gezins)teams: het onderzoek 'Teamwerk in de Wijk' en het onderzoek van de Academische Werkplaats Gezin aan Zet. Twee regio's met een zeer uiteenlopende wijze van organisatie van de Jeugd- (en Gezins)teams worden in dit artikel met elkaar vergeleken: de gemeente Den Haag en de samenwerkingsregio Holland Rijnland. Deze regio's verschillen van elkaar in de directe aansturing: de Jeugd(en Gezins)teams in Den Haag worden aangestuurd door een manager, terwijl de teams in Holland Rijnland in sterke mate zelfsturend zijn en worden ondersteund door een coach. In onze vergelijking tussen deze twee regio's gaan we in op de manier waarop de teams worden aangestuurd, de samenwerking binnen de teams en de rol van regels en procedures. De onderzoeksvraag in dit artikel luidt: in hoeverre heeft de wijze van organisatie van de Jeugd- (en Gezins)teams invloed op het teamfunctioneren? Daarbij richten we ons op een viertal aspecten die ten grondslag liggen aan het teamfunctioneren, welke in het theoretisch kader verder gespecificeerd worden.

Allereerst zullen we ingaan op de verschillende wijzen van organiseren in de twee regio's, waarna verschillende aspecten worden beschreven die volgens de literatuur bijdragen aan het functioneren van de teams. Dit mondt uit in een aantal hypothesen over te verwachten verschillen in het functioneren van de teams in beide regio's.

\section{Achtergrond: Jeugd- (en Gezins)teams in Den Haag en Holland Rijnland}

De gemeente Den Haag is onderdeel van de jeugdhulpregio Haaglanden en stuurt de Jeugd- (en Gezins)teams op gemeentelijk niveau aan (Inkoopplan Jeugdhulp 2016, 2015). In Den Haag heeft elk stadsdeel één of meerdere Jeugd- (en Gezins)teams, afhankelijk van de grootte van het stadsdeel. De Jeugd- (en Gezins)teams zijn multidisciplinaire teams, waarin ongeveer acht tot twaalf professionals werken. De professionals werken vanuit verschillende moederorganisaties met specialismen op het gebied van onder andere opvoedhulp, veiligheid en bescherming, lichtverstandelijke beperking, specialistische geestelijke gezondheidszorg en sociaalmaatschappelijk werk (Eilander e.a., 2017).

In de jeugdhulpregio Holland Rijnland hebben dertien gemeenten ervoor gekozen om het opdrachtgeverschap van de jeugdhulp gezamenlijk vorm te geven. Begin 2016 is de coöperatie opgericht, een samenwerkingsverband van verschillende jeugdhulpaanbieders. De coöperatie is verantwoordelijk voor de uitvoering van de jeugdhulp door de Jeugd- (en Gezins)teams in de regio. De gemeenten van het regionale samenwerkingsverband Holland Rijnland hebben een contractuele relatie met de coöperatie (Basisdocument coöperatie Jeugd en Gezinsteams Holland Rijnland, 2015). In Holland Rijnland bestaan de multidisciplinaire Jeugd- (en Gezins)teams eveneens uit ongeveer acht tot twaalf professionals. De professio- 
nals zijn structureel gedetacheerd vanuit de moederorganisaties, die overeenkomstige specialismen hebben als in Den Haag. De moederorganisaties maken deel uit van de coöperatie.

De directe aansturing van de Jeugd- (en Gezins)teams in Den Haag is anders dan de aansturing van de teams in Holland Rijnland. In Den Haag worden de teams aangestuurd door een manager. De teammanager heeft een leidende rol en neemt beslissingen waar nodig (Eilander e.a., 2017). In Holland Rijnland zijn de Jeugd(en Gezins)teams daarentegen in sterke mate zelfsturend. In de dagelijkse praktijk betekent zelfsturing dat de teams binnen de wettelijke kaders zelf beslissingen nemen, het werk organiseren en een hoge eigen verantwoordelijkheid hebben (Omschrijving Dienstverlening Jeugd- en Gezinsteam Holland Rijnland, 2015). De teams worden begeleid door een coach, die op hoofdlijnen verbindt en stuurt op zelfsturing. De coach heeft dus geen leidende rol, maar een begeleidende rol (Eilander e.a., 2017).

\section{Theoretisch kader}

Om te kunnen onderzoeken wat de invloed is van de verschillende organisatiewijzen in Den Haag en Holland Rijnland op verschillende aspecten van teamfunctioneren is het van belang eerst te bepalen welke aspecten we gaan vergelijken. Vervolgens formuleren wij op basis van de literatuur verwachtingen over de verschillen tussen beide regio's.

Het is niet zo eenvoudig om de prestaties van een Jeugd- (en Gezins)team, een relatief nieuw fenomeen in Nederland, vast te stellen. Er bestaat echter omvangrijke wetenschappelijke literatuur over teams en de aspecten die bijdragen aan hun functioneren (Campion \& Medsker, 1993; Dunphy \& Bryant, 1996; Kuipers \& Groeneveld, 2014; Kuipers \& Stoker, 2009). In de onderstaande secties gaan wij in op een aantal aspecten die ten grondslag liggen aan de prestaties van teams: teamwerk, leiderschap en regels en procedures.

\section{Teamwerk}

Kuipers en Groeneveld (2014) beschrijven vier aspecten van teamwerk die van invloed zijn op hoe teams presteren: zelfmanagement, doelgerichte samenwerking, taakgerichte samenwerking en samenwerking met ketenpartners. Hieronder gaan wij in op deze aspecten van teamwerk.

Zelfmanagement is een belangrijk aspect dat positief bijdraagt aan het functioneren van teams, omdat het een positief effect heeft op onder andere de efficiëntie van teams (Campion \& Medsker, 1993; Kuipers \& Groeneveld, 2014). Zelfmanagement is een concept dat te maken heeft met autonomie (Campion \& Medsker, 1993). Autonomie gaat over de mate van ruimte die individuen en teams hebben om zelf het werk in te delen en beslissingen te nemen. Bij zelfmanagement gaat het om de mate waarin teams die ruimte daadwerkelijk krijgen (Dunphy \& Bryant, 1996) en benutten voor het nemen van initiatief en verantwoordelijkheid (Kuipers \& Groeneveld, 2014). Sommige teams - zoals zogenaamde zelfsturende teams - zijn op zo'n manier georganiseerd dat zij bijzonder veel autonomie krij- 
gen en een hoge mate van zelfmanagement hebben (Groeneveld \& Kuipers, 2014). Dit betekent echter niet dat niet-zelfsturende teams geen hoge mate van zelfmanagement kunnen hebben. Kuipers en Groeneveld (2014) beschrijven dat de basis voor zelfmanagement zowel zelfsturing als sturing kan zijn. Sturing kan belangrijk zijn voor het stimuleren van teams om als team te reflecteren op de werkwijze en om als team zelfstandig te werken. Bij zelfmanagement gaat het om het gedrag van het team betreffende het plannen en verdelen van werk en het nemen van beslissingen en verantwoordelijkheid. In het geval van de Jeugd- (en Gezins)teams gaat het er dus om in hoeverre zij de ruimte krijgen en nemen om zelf beslissingen en initiatieven te nemen om zich als team verder te ontwikkelen.

Een tweede aspect van teamwerk dat bijdraagt aan het teamfunctioneren is doelgerichte samenwerking (Kuipers \& Groeneveld, 2014). Dit verwijst naar de mate waarin teamleden samenwerken om de teamdoelen te behalen. Uit onderzoek blijkt dat het hebben van gezamenlijke doelen positief bijdraagt aan het reflectievermogen (Tjosvold, Tang \& West, 2004) en de effectiviteit van teams (Poulton \& West, 1999). Het hebben van duidelijke doelen als team (Van der Hoek, Groeneveld \& Kuipers, 2018) evenals een hoge mate van doelgerichte samenwerking zijn belangrijk voor de prestaties van teams. Doelgerichte samenwerking kan ervoor zorgen dat teamleden meer bevlogen zijn, wat kan resulteren in het leveren van betere prestaties (Kuipers \& Groeneveld, 2014). In teams met een hoge mate van doelgerichte samenwerking is er een hoge mate van cohesie en onderling vertrouwen tussen de teamleden. Zowel bij goede als slechte prestaties neemt het team als één geheel zijn verantwoordelijkheid (Kuipers \& Groeneveld, 2014). Om doelgericht te kunnen samenwerken is het noodzakelijk dat het voor alle teamleden duidelijk is wat het team probeert te bereiken en hoe dat dient te gebeuren. Dit is van belang voor multidisciplinaire teams, zoals de Jeugd- (en Gezins)teams, waar professionals met verschillende expertise vanuit verschillende moederorganisaties werken.

Een derde onderdeel van teamwerk is taakgerichte samenwerking. Taakgerichte samenwerking gaat over de mate waarin teamleden informatie en kennis uitwisselen over het werk. Het stelt teamleden in staat om van elkaar te leren en nieuwe ideeën op te doen (Kuipers \& Groeneveld, 2014; Van Knippenberg, De Dreu \& Homan, 2004). Het delen van kennis en informatie kan zorgen voor een hogere kwaliteit van de taken die worden uitgevoerd (Kuipers \& Stoker, 2009) en voor meer bevlogen teamleden, waardoor er vaak betere prestaties worden behaald. Daarnaast is het verdiepen en uitbreiden van kennis van belang voor het functioneren van teams (Kuipers \& Groeneveld, 2014; Van Knippenberg e.a., 2004). Taakgerichte samenwerking is dus een belangrijk kenmerk van goed functionerende teams. Zeker voor multidisciplinaire teams zoals de Jeugd- (en Gezins)teams is het uitwisselen van informatie van groot belang, omdat er een grote diversiteit is aan kennis en kunde.

Een laatste en vierde onderdeel van teamwerk dat belangrijk is voor het teamfunctioneren is de samenwerking met ketenpartners (in het geval van dit onderzoek de externe samenwerking met partners in de wijk), door Kuipers en Groene- 
veld (2014) ook wel stakeholdergerichte samenwerking genoemd. Een goede samenwerking met ketenpartners kan ervoor zorgen dat er betere hulpverlening wordt geboden (Kuipers \& Stoker, 2009). In de samenwerking kunnen ketenpartners teams van informatie en feedback voorzien. Teams kunnen daartegenover ketenpartners informatie geven over waar ze als team voor staan en kunnen aansluiten bij de wensen en behoefte van partners (Ancona, 1990; Kuipers \& Groeneveld, 2014). Dit kan een goede samenwerking bevorderen, wat de hulpverlening ten goede kan komen. Het blijkt dat de samenwerking met ketenpartners een belangrijk aspect van teamfunctioneren is en van invloed is op de teamprestaties (Ancona, 1990; Kuipers \& Groeneveld, 2014). In het geval van Jeugd- (en Gezins)teams gaat het om het initiëren en onderhouden van relaties met ketenpartners, zoals informele hulpverleners, huisartsen, politieagenten en andere hulpverleners. Op die manier beschikt het team over meer kennis, heeft het toegang tot additionele middelen en expertise en kan de hulp optimaal op de situatie van de cliënt worden aangepast (Kuipers \& Groeneveld, 2014).

\section{Leiderschap}

Leiderschap is een drijvende kracht achter motivatie, persoonlijke ontwikkeling, verandering en prestaties (Dinh e.a., 2014). Leiderschap kan gedefinieerd worden als het uitoefenen van invloed op volgers om zo hun gedrag in groepen of organisaties te sturen, structureren en ondersteunen (Knies, Jacobsen \& Tummers, 2016). Leidinggevenden ondersteunen teams in het behalen van doelen en in het ontwikkelen van teambevlogenheid (Kuipers \& Groeneveld, 2014). Hoewel veel teams voor een deel in hun eigen leiderschapsbehoefte voorzien, is er in een groot aantal teams behoefte aan formeel leiderschap door een leidinggevende (Morgeson, DeRue \& Karam, 2010). Er bestaan echter verschillende opvattingen over hoe dit leiderschap eruit dient te zien. In dit artikel gaan we in op twee verschillende benaderingen van leiderschap: transformationeel leiderschap en dienend leiderschap.

Bij transformationeel leiderschap formuleren en communiceren leiders een aantrekkelijke visie om de taken van teamleden te verbinden met de uiteindelijke doelen van het team. Leidinggevenden met een transformationele leiderschapsbenadering motiveren teamleden om de doelen van de organisatie voorop te stellen, boven hun persoonlijke belangen, waarden en doelen (Jensen e.a., 2019). Bij transformationeel leiderschap wordt de ontwikkeling van de teamleden gezien in de context van wat goed is voor het team om als team beter te presteren (Van Dierendonck, 2011).

Dienend leiderschap richt zich op het ondersteunen en ontwikkelen van de teamleden. Dienende leiders creëren condities om het welzijn en het functioneren van de teamleden te verbeteren. Deze vorm van leiderschap heeft niet direct optimale teamprestaties voor ogen, maar richt zich op het vervullen van de behoeftes van individuele teamleden om persoonlijke en professionele ontwikkeling te stimuleren. De ontwikkeling van teamleden kan zo indirect de teamprestaties ten goede komen (Van Dierendonck, 2011). Bij dienende leiders zijn dus de individuele 
teamleden het belangrijkste doel, terwijl transformationele leiders meer gericht zijn op de doelen van het team als geheel (Parolini, Patterson \& Winston, 2009; Van Dierendonck, 2011).

Leiderschap kan dynamisch zijn en veranderen door de tijd heen, wat het mogelijk maakt dat binnen één team meerdere soorten leiderschap voorkomen (Morgeson e.a., 2010). De passendheid en de effectiviteit van beide benaderingen kan volgens Morgeson en anderen (2010) afhangen van de 'levensfase' waarin het team zich bevindt. In teams die relatief nieuw zijn, is met name behoefte aan richtinggevend, transformationeel leiderschap, terwijl teams die al langer actief zijn met name om ondersteunend, dienend leiderschap vragen. In het geval van de Jeugd- (en Gezins)teams zijn de teams relatief nieuw, maar verschillen zij ook in organisatiestructuur, waardoor zowel overeenkomstige als verschillende leiderschapsstijlen ingezet kunnen worden.

\section{Regels en procedures}

'Bureaucratie' kan een belangrijke factor zijn die het functioneren van teams beïnvloedt (Groeneveld \& Kuipers, 2014). Te veel bureaucratie wordt onder andere gekenmerkt door te veel regels en voorschriften, wat kan resulteren in overbodige complexe processen die voor vertragingen in het werk zorgen (Groeneveld, 2016). Meer bureaucratie in de jeugdhulp kan maken dat het langer duurt voordat zorg geleverd wordt en dat er minder ruimte is voor ontwikkeling en kwaliteit (Friele e.a., 2018). Een van de ambities van de Jeugdwet van 2015 is het verminderen van de regels en procedures en dus de bureaucratie waarmee jeugdhulpprofessionals te maken hebben. Er zijn indicaties dat die ambitie nog niet is waargemaakt (Arum \& Van den Enden, 2018; Steijn \& Van der Voet, 2017; Friele e.a., 2018). Zo komt in de Eerste evaluatie Jeugdwet van Friele en anderen (2018) naar voren dat de administratieve last niet is afgenomen en er juist meer bureaucratie wordt ervaren. Een belangrijke nuancering is echter dat regels en procedures niet per definitie slecht zijn. Regels en vastomlijnde kaders kunnen onzekerheid wegnemen en daarbij zijn regels, procedures en administratieve taken tot op zekere hoogte noodzakelijk om het werk van Jeugd- (en Gezins)teams voorspelbaar en controleerbaar te maken (Groeneveld, 2016), zeker gezien het gevoelige karakter van het werk. Een leidinggevende kan hier een belangrijke rol in spelen. Een belangrijk aspect van leiderschap is namelijk het duiden en verduidelijken van regels, procedures en richtlijnen en daarbij het toezien op de naleving hiervan (Casimir, 2001). Belangrijk is om in kaart te brengen hoe professionals in de teams regels beleven: zien zij regels als duidelijk, consistent en ondersteunend aan het werk, of ervaren zij dat regels overbodig en hinderlijk zijn?

\section{Hypothesen}

De centrale verwachting in dit artikel is dat de wijze waarop de Jeugd- (en Gezins)teams georganiseerd zijn, gevolgen heeft voor een aantal aspecten van teamfunctioneren. Gegeven de organisatorische verschillen tussen de gemeente Den Haag en de regio Holland Rijnland, formuleren wij op basis van bovenstaande literatuur een drietal verwachtingen. 
1 De eerste verwachting heeft betrekking op een van de vier onderdelen van teamwerk, namelijk zelfmanagement. Sommige teams, zoals zelfsturende teams, krijgen, zoals eerder beschreven, meer autonomie en ervaren over het algemeen een hoge mate van zelfmanagement (Kuipers \& Groeneveld, 2014). Een eerste verwachting is daarom dat de zelfsturende teams uit Holland Rijnland door een hogere mate van zelfmanagement worden gekenmerkt dan de teams uit Den Haag. Hierbij wordt verwacht dat de professionals uit de zelfsturende teams meer ruimte krijgen en nemen om zelf beslissingen te nemen. Over de andere aspecten van teamwerk (taakgerichte samenwerking, doelgerichte samenwerking en samenwerking met ketenpartners) zijn geen verwachtingen; hier wordt exploratief onderzocht of er verschillen zijn tussen beide regio's.

2 Een tweede verwachting heeft betrekking op leiderschap. In Den Haag hebben de Jeugd- (en Gezins)teams een teammanager die de teams leidt, terwijl in Holland Rijnland de teams een coach hebben die de teams ondersteunt. Transformationeel leiderschap is een benadering vanuit het formele leiderschap (Morgeson e.a., 2010) en is meer richtinggevend (Kuipers \& Groeneveld, 2014). De verwachting is daarom dat de professionals in Den Haag, die een formeel leidinggevende hebben, meer transformationeel leiderschap zullen ervaren dan de professionals in Holland Rijnland. Daarnaast wordt verwacht dat de professionals in Holland Rijnland, die meer een ondersteunende leidinggevende hebben (een coach), juist meer dienend leiderschap zullen ervaren dan de professionals in Den Haag. Dienend leiderschap is meer ondersteunend en gericht op de ontwikkeling van teamleden (Van Dierendonck, 2011).

3 Een derde verwachting heeft betrekking op regels en procedures. De vraag is hoe de professionals regels en procedures ervaren. Verwacht wordt dat de professionals uit Den Haag een hogere mate van gepercipieerde kwaliteit van regels zullen ervaren dan de professionals uit Holland Rijnland. Waar de professionals uit Holland Rijnland worden ondersteund door een coach, worden de professionals uit Den Haag aangestuurd door een manager. De manager heeft de rol van een formeel leidinggevende en heeft expliciet de taak om aandacht te besteden aan regels en procedures. De professionals uit Den Haag zullen daarom naar verwachting meer kwaliteit ervaren van regels en procedures dan de professionals uit Holland Rijnland. Daarnaast wordt verwacht dat door de juist hoge betrokkenheid van de managers in Den Haag bij regels en procedures, er meer onnodige regels en procedures worden ondervonden door de professionals.

\section{Methode}

\section{Participanten en instrumenten}

In dit artikel worden de resultaten van twee onafhankelijke studies gecombineerd om een goede vergelijking te kunnen maken tussen de regio Holland Rijnland en de gemeente Den Haag. Voor het beantwoorden van de onderzoeksvraag is er 
gebruikgemaakt van 'mixed-methods'. De resultaten vanuit het kwantitatieve onderzoek worden geïnterpreteerd met behulp van kwalitatieve data om op genuanceerde wijze de onderzoeksvraag te beantwoorden. Dit is een gangbare methode bij complexe en praktijkgerichte vraagstukken waarop mogelijk meerdere variabelen van invloed zijn (Tashakorri \& Teddlie, 1998).

Door de afdelingen Bestuurskunde van de Universiteit Leiden en de Erasmus Universiteit Rotterdam wordt door middel van kwantitatieve vragenlijsten onderzoek gedaan naar het functioneren van Jeugd- (en Gezins)teams. De Academische Werkplaats Gezin aan Zet brengt door middel van actieonderzoek onder andere werkzame en belemmerende factoren van het werken in een Jeugd- (en Gezin)team in kaart. De Academische Werkplaats Gezin aan Zet is een samenwerkingsverband waar praktijk, beleid, onderwijs en wetenschap worden verbonden. De onderzoeken vullen elkaar inhoudelijk goed aan en vinden gelijktijdig plaats in dezelfde doelgroep, maar vanuit een andere benadering. De resultaten van de afzonderlijke onderzoeken worden gecombineerd en vervolgens geanalyseerd, om een genuanceerd beeld te schetsen van de huidige situatie waarin de Jeugd- (en Gezinsteams) zich bevinden (Wisdom e.a., 2012).

In het onderzoek vanuit de Universiteit Leiden en Erasmus Universiteit Rotterdam is een vragenlijst afgenomen die verschillende aspecten van teamfunctioneren belicht. De vragenlijst bestaat uit gevalideerde meetschalen over de aspecten van teamwerk, leiderschap, regels en procedures en gepercipieerde teamprestaties (Steijn, Van der Voet \& Huizenga, 2017). De vragen worden beantwoord op een vijfpuntsschaal, waarbij één staat voor helemaal mee oneens en vijf voor helemaal mee eens. Deze online vragenlijst is in het voorjaar van 2017 onder de professionals van alle Jeugd- (en Gezins)teams in Den Haag en de regio Holland Rijnland uitgezet. De regio Holland Rijnland telde op het moment van afname 24 Jeugd(en Gezins)teams, begeleid door in totaal acht teamcoaches. De vragenlijst is door 113 medewerkers van de 262 medewerkers uit Holland Rijnland volledig ingevuld, wat correspondeert met een responspercentage van 43,5 procent. Den Haag telde op het moment van afname van de vragenlijst 21 Jeugd- (en Gezins)teams en zes stedelijke teams, aangestuurd door vijftien managers. De vragenlijst is in Den Haag door 124 van de 255 medewerkers volledig ingevuld, wat correspondeert met een responspercentage van 48,2 procent.

In totaal zijn de percepties van 237 professionals uit de onderzochte regio's meegenomen in het onderzoek. Het is van belang te onderstrepen dat alle metingen de percepties van professionals over het eigen team betreffen. Van de medewerkers in Holland-Rijnland is 88 procent vrouw. In Den Haag is dat 95 procent. De gemiddelde leeftijd in Holland Rijnland (41,9 jaar) is iets hoger dan in Den Haag (37,8 jaar). Ook zijn medewerkers in Holland Rijnland gemiddeld iets langer werkzaam als hulpverlener. Het gemiddelde aantal dienstjaren is 16,8 in Holland Rijnland, versus 11,7 dienstjaren in Den Haag. Qua opleidingsniveau zijn de professionals in Holland Rijnland en Den Haag goed vergelijkbaar; respectievelijk 98,2 procent en 97,5 procent van de respondenten heeft een hbo- of universitair diploma. 
De cijfers uit het onderzoek van de Universiteit Leiden en de Erasmus Universiteit Rotterdam worden aangevuld met kwalitatieve gegevens afkomstig uit het onderzoek van de Academische Werkplaats Gezin aan Zet. De Academische Werkplaats Gezin aan Zet heeft in het najaar van 2016 semigestructureerde interviews afgenomen met 32 professionals uit Den Haag en Holland Rijnland. Vanuit elke regio hebben 16 professionals uit drie verschillende teams deelgenomen. Het interview richt zich op de ervaringen van professionals met het werken in een Jeugd- (en Gezins)team en omvat onderwerpen als teamontwikkeling, besluitvorming, interne en externe samenwerking en leiderschap.

\section{Analysestrategie}

In dit artikel worden zowel de kwantitatieve als de kwalitatieve resultaten gepresenteerd. Voor het kwantitatieve gedeelte is in SPSS (versie 23) met een onafhankelijke t-test onderzocht of er op de groepsgemiddelden van de variabelen teamwerk, leiderschap en regels en procedures statistisch significante verschillen bestaan tussen de regio Holland Rijnland en de gemeente Den Haag. Voor het kwalitatieve gedeelte zijn geluidsopnamen van de interviews getranscribeerd en gecodeerd in Atlas-Ti (versie 7). Na elk interview kwamen de onderzoekers samen om de codering te vergelijken, verschillen te bespreken en aanvullende codes toe te voegen indien nodig, zodat er overeenstemming bereikt werd. De transcripten zijn op basis van frameworkanalyse gecodeerd. Dit betekent dat de codes gedeeltelijk gebaseerd zijn op de thema's uit een topiclijst, maar dat er ook ruimte was voor nieuwe perspectieven (Pope, Ziebland \& Mays, 2000). De voorlopige conclusies zijn door middel van 'member check'-bijeenkomsten met de professionals uit de Jeugd- (en Gezins)teams gevalideerd.

\section{Resultaten}

In deze sectie worden de resultaten beschreven voor de variabelen teamwerk, leiderschap en regels en procedures vanuit de visie van de professional.

\section{Teamwerk}

De resultaten in tabel 1 laten zien dat de professionals vrij positief oordelen over alle vier de aspecten van teamwerk: doelgerichte samenwerking, samenwerking met ketenpartners, taakgerichte samenwerking en zelfmanagement. Als we de vier aspecten van teamwerk onderling vergelijken, zijn de professionals uit Holland Rijnland en Den Haag het meest positief over de doelgerichte samenwerking. Er is op dit aspect geen significant verschil tussen beide regio's gevonden. Professionals uit beide regio's geven, volgens de kwantitatieve data, hiermee aan dat er voldoende cohesie en vertrouwen binnen de teams is om gezamenlijk te werken aan het behalen van de teamdoelen. Uit de interviews met de professionals wordt hetzelfde geconcludeerd. Zo wordt er in beide regio's veel geïnvesteerd in teamontwikkeling binnen de Jeugd- (en Gezins)teams. Professionals vinden het belangrijk om hier tijd en ruimte voor vrij te maken om elkaar niet alleen werkinhoudelijk goed te kennen, maar ook op persoonlijk vlak. Professionals geven aan dat de communicatie en omgang zijn verbeterd door de investering in teamont- 
Tabel 1 Percepties professionals Den Haag en Holland Rijnland: gemiddelde scores over de centrale variabelen

\begin{tabular}{|c|c|c|c|}
\hline & Den Haag' & Holland-Rijnland ${ }^{2}$ & Significantie $^{3}$ \\
\hline Zelfmanagement & $3,73(, 59)$ & $3,93(, 54)$ & $\begin{array}{l}\text { Statistisch significant } \\
\text { verschil met } p<, 0 \text { I }\end{array}$ \\
\hline $\begin{array}{l}\text { Doelgerichte } \\
\text { samenwerking }\end{array}$ & $4,04(, 60)$ & $4,04(, 62)$ & \\
\hline $\begin{array}{l}\text { Taakgerichte } \\
\text { samenwerking }\end{array}$ & $3,77(, 58)$ & $3,96(, 58)$ & $\begin{array}{l}\text { Statistisch significant } \\
\text { verschil met } p<, 05\end{array}$ \\
\hline Externe samenwerking & $3,52(, 68)$ & $3,5 \mathrm{I}(, 74)$ & \\
\hline $\begin{array}{l}\text { Transformationeel lei- } \\
\text { derschap }\end{array}$ & $3,47(, 91)$ & $3,32(, 84)$ & \\
\hline Dienend leiderschap & $3,70(, 79)$ & $3,60(, 68)$ & \\
\hline Kwaliteit van regels & $3,12(, 56)$ & $2,82(, 62)$ & $\begin{array}{l}\text { Statistisch significant } \\
\text { verschil met } \mathrm{p}<, 00 \text { I }\end{array}$ \\
\hline $\begin{array}{l}\text { Overbodige regels en } \\
\text { procedures }{ }^{4}\end{array}$ & $5,9(2,11)$ & $5, I(2,20)$ & $\begin{array}{l}\text { Statistisch significant } \\
\text { verschil met } \mathrm{p}<, 0 \text { l }\end{array}$ \\
\hline
\end{tabular}

${ }^{1} \mathrm{~N}=124$ professionals in Den Haag.

${ }^{2} \mathrm{~N}=113$ professionals in Holland Rijnland.

${ }^{3}$ Een statistisch significant verschil tussen de score van Den Haag en Holland Rijnland betekent dat het verschil met een zekerheidspercentage van 95 procent, 99 procent dan wel 99,9 procent van de steekproef naar de volledige populatie van medewerkers gegeneraliseerd kan worden.

${ }^{4}$ In tegenstelling tot de overige variabelen zijn 'overbodige regels' gemeten op een tienpuntsschaal, waarbij een score van 10 duidt op 'zeer veel overbodige regels en procedures'.

wikkeling, dat er meer onderling vertrouwen is en steeds meer een gemeenschappelijke basisvisie, wat de doelgerichte samenwerking en dus het teamfunctioneren ten goede komt.

De samenwerking met ketenpartners blijkt uit de kwantitatieve analyse het minst goed beoordeeld te worden in beide regio's. Dit is in overeenstemming met het beeld dat uit de interviews naar voren komt. De professionals uit de regio Holland Rijnland en uit de gemeente Den Haag geven aan dat de kwaliteit van de samenwerking per ketenpartner en per professional verschilt. Uit de interviews komen ook suggesties naar voren voor verbeteringen in de samenwerking met sommige ketenpartners. Zo ervaren professionals dat er veel taken bij het team worden neergelegd die mogelijk ook bij ketenpartners kunnen liggen, en het is niet altijd duidelijk bij wie de verantwoordelijkheid nu ligt. Daarnaast zorgen wachtlijsten en budgetplatfonds voor knelpunten in de samenwerking tussen ketenpartners en professionals uit de Jeugd- (en Gezins)teams. Professionals uit de Jeugd- (en Gezinsteams) bieden hierdoor vaak overbruggende hulp, wat vaak extra tijd kost en voor een verhoogde werkdruk zorgt. Professionals noemen dat transparante en heldere communicatie, continuïteit van de contactpersonen, het bespreken van taken en wederzijdse verwachtingen en het evalueren van de samenwerking essentiële voorwaarden zijn in de samenwerking met ketenpartners. 
De gemeente Den Haag en de regio Holland Rijnland verschillen dus niet significant van elkaar op de onderdelen doelgerichte samenwerking en externe samenwerking. Wel wordt een significant verschil gevonden op de andere twee aspecten van teamwerk: taakgerichte samenwerking en zelfmanagement (zie tabel 1). Uit de kwantitatieve data blijkt dat de professionals in Holland Rijnland iets positiever over taakgerichte samenwerking zijn dan de professionals in Den Haag. Dit betekent dat de professionals in Holland Rijnland over het algemeen ervaren dat er meer kennis binnen het team wordt uitgewisseld. In beide regio's zijn er vaste vergadermomenten waar professionals informatie en ervaringen uitwisselen over onder andere de geboden hulpverlening. Professionals uit zowel Holland Rijnland als Den Haag geven in de interviews aan deze vaste momenten waardevol te vinden, onder andere voor het contact met elkaar. De professionals in Holland Rijnland zijn, vanwege het zelfsturende karakter, echter genoodzaakt meer te communiceren over de werkprocessen. De vergaderfrequentie in Holland Rijnland ligt dan ook hoger dan in Den Haag. Tevens wordt in Den Haag door een aantal professionals aangegeven dat het feit dat sommige Jeugd- (en Gezins)teamprofessionals die in hetzelfde team werken verschillende werklocaties hebben, van invloed kan zijn op de omgang en communicatie tussen professionals.

Voor de mate van zelfmanagement blijkt uit de kwantitatieve data dat de twee regio's significant van elkaar verschillen. In Holland Rijnland wordt de mate van zelfmanagement iets hoger beoordeeld dan in Den Haag. Dit houdt in dat de zelfsturende teams in Holland Rijnland een hogere mate van zelfmanagement ervaren. Uit de interviews blijkt dat de professionals in Holland Rijnland andere taken op zich nemen en dat de coach een andere rol heeft in besluitvormingsprocessen ten opzichte van de manager in Den Haag. Zo nemen de professionals in Holland Rijnland meer besluiten rondom organisatorische zaken, zoals het verdelen van het scholingsbudget en het vormgeven van functioneringsgesprekken. Daarbij besteden de professionals in Holland Rijnland veel aandacht aan besluitvormingsprocessen, waar dit in Den Haag veel minder naar voren komt. De professionals in Den Haag vinden het belangrijk om bij het besluitvormingsproces betrokken te worden, maar vinden het ook prettig als een manager knopen doorhakt en de regie neemt wanneer dit nodig is.

\section{Leiderschap}

In de vragenlijst is aan de professionals gevraagd in hoeverre zij transformationeel en dienend leiderschapsgedrag van hun manager dan wel teamcoach ervaren. Het ervaren leiderschap binnen de teams in Holland Rijnland en Den Haag blijkt niet significant van elkaar te verschillen. Dit betekent dat de professionals in Den Haag, in tegenstelling tot de verwachting, niet meer transformationeel leiderschap ervaren dan de professionals uit Holland Rijnland. De professionals uit Holland Rijnland ervaren ook niet meer dienend leiderschap dan de professionals uit Den Haag. Uit de interviews blijkt dat ondanks dat de rollen van de coaches in Holland Rijnland en de managers in Den Haag van elkaar verschillen, de professionals grotendeels overeenkomstige verwachtingen hebben van een manager of 
een coach. Zo verwachten professionals uit beide regio's dat een manager/coach meedenkt in bepaalde processen, structuur biedt, een ondersteunende rol heeft, oog heeft voor persoonlijke doelen van de professionals en betrokken is. Daarnaast vinden professionals het belangrijk dat een manager/coach de teamontwikkeling stimuleert en open en transparant communiceert.

\section{Regels en procedures}

Uit de kwantitatieve data blijkt dat professionals uit beide regio's de kwaliteit van regels en procedures vrij laag beoordelen. Holland Rijnland en Den Haag verschillen daarbij statistisch significant van elkaar, zowel in de waardering van de kwaliteit van regels en procedures als de hoeveelheid overbodige regels en procedures. Er kan worden gesteld dat de professionals in Den Haag de kwaliteit van regels over het algemeen positiever waarderen, maar dat zij ook meer overbodige regels ervaren. Al met al lijken regels - zowel de positieve als de negatieve beleving ervan - dus een belangrijk thema te zijn voor de teams in Den Haag. Uit de interviews blijkt dat de manager in Den Haag een belangrijke rol speelt bij het creëren van voorwaarden, bieden van kaders en verduidelijken van regels en procedures. De (zelfsturende) professionals uit Holland Rijnland ervaren minder overbodige regels en procedures, maar geven ook aan dat de regels en procedures niet altijd helder zijn en kaders en richtlijnen voor hun gevoel soms ontbreken om een goed besluit te kunnen nemen. Uit de interviews komt een gemengd beeld naar voren. Enerzijds hebben de professionals in Holland Rijnland behoefte aan kaders die richting geven, anderzijds willen zij ook niet beperkt worden in hun vrijheid, zodat zij hulp op maat kunnen bieden.

\section{Discussie}

De transitie van de jeugdhulp naar de gemeente in 2015 heeft gezorgd voor een omslag in het jeugdhulpstelsel. De lokale Jeugd- (en Gezins)teams hebben een cruciale rol in dit nieuwe jeugdhulpstelsel en moeten helpen om de transformatiedoelen te bereiken. De teamliteratuur leert ons dat het teamfunctioneren belangrijk is voor teamprestaties. Er bestaan lokaal verschillen in de manier van organiseren van de Jeugd- (en Gezins)teams, wat mogelijk van invloed is op bepaalde aspecten van het teamfunctioneren (Kuipers \& Groeneveld, 2014). Om te onderzoeken of de wijze van organiseren van invloed is op het teamfunctioneren vergeleken we twee regio's die voor een geheel andere wijze van organiseren hebben gekozen: de regio Holland Rijnland, waar de teams in sterke mate zelfsturend zijn, en de gemeente Den Haag, waar de teams aangestuurd worden door een manager. De bevindingen uit dit onderzoek leveren inzichten op voor beleidsmakers en bestuurders die van belang kunnen zijn voor het doorontwikkelen en organiseren van Jeugd- (en Gezins)teams.

Uit de analyse van de kwantitatieve en kwalitatieve resultaten kan worden afgeleid dat er ondanks het grote verschil in aansturing veel overeenkomsten zijn tussen de regio's op verschillende aspecten van teamfunctioneren. Desondanks lijkt de wijze van organisatie op een aantal aspecten van het teamfunctioneren van invloed te zijn. 
Zo wordt de taakgerichte samenwerking in Holland Rijnland hoger beoordeeld dan in Den Haag. De professionals uit de zelfsturende teams ervaren dat er meer kennis wordt uitgewisseld. Door het zelfsturende karakter van de teams zijn professionals genoodzaakt regelmatig onderling te communiceren over werkprocessen. Een factor die hierop mogelijk ook van invloed kan zijn geweest, zijn de verschillende werklocaties van professionals. Uit het kwalitatieve gedeelte van het onderzoek kwam naar voren dat in sommige teams uit Den Haag professionals op verschillende locaties werken, wat van invloed is op de communicatie en omgang, een belangrijke voorwaarde voor het delen van informatie. Voor multidisciplinaire Jeugd- (en Gezins)teams is het delen van informatie en kennis van groot belang; het maakt dat professionals leren, nieuwe ideeën op doen, de kwaliteit van taken hoger is en er vaak betere prestaties worden geleverd (Kuipers \& Groeneveld, 2014).

Op de variabelen doelgerichte samenwerking en samenwerking met ketenpartners vonden we geen verschillen tussen de regio's. Ook uit het kwalitatieve gedeelte van het onderzoek vonden we geen aanwijzingen dat de organisatiewijze van invloed is op deze variabelen. Hoewel alle vier de aspecten van teamwerk positief zijn beoordeeld door de professionals, valt het op dat professionals uit beide regio's het minst positief zijn over de samenwerking met ketenpartners. Dit komt overeen met eerder onderzoek: er is steeds meer samenwerking met ketenpartners, maar er valt op dit punt ook nog veel winst te behalen (Arum \& Van den Enden, 2018; Friele e.a., 2018).

Zoals verwacht ervaren de professionals uit zelfsturende teams in Holland Rijnland een hogere mate van zelfmanagement dan de professionals uit de teams in Den Haag. Op basis van de kwalitatieve en kwantitatieve resultaten kan geconcludeerd worden dat de professionals in Holland Rijnland door het zelfsturende karakter daadwerkelijk meer ruimte ervaren om zelf beslissingen te nemen. Dit is in lijn met de bevindingen van Groeneveld en Kuipers (2014), namelijk dat zelfsturende teams over meer autonomie en een hogere mate van zelfmanagement beschikken. De teams in Holland Rijnland worden ondersteund door een coach, maar deze laat besluitvormingsprocessen doorgaans aan het team over. In Den Haag komen deze besluitvormingsprocessen minder ter sprake; een manager heeft hier een meer sturende rol en neemt dan ook vaker besluiten voor het team. In de context van street level bureaucrats zoals jeugdhulpprofessionals kan autonomie een cruciale vereiste in het werk zijn (Lipsky, 1980): de complexiteit van het werk vereist dat professionals indien nodig de ruimte hebben om eigen keuzes te maken, om zo voor iedere cliënt een hoge kwaliteit van hulpverlening te garanderen. De mate van zelfmanagement is daarom bij uitstek een belangrijke overweging in het organiseren van Jeugd- en (Gezins)teams.

Tegen onze verwachtingen in blijkt uit zowel het kwantitatieve als het kwalitatieve gedeelte van het onderzoek dat er geen verschillen zijn in het gepercipieerde leiderschap, zowel wat betreft het transformationele als het dienend leiderschap. Dit is opvallend, omdat de aansturing van de teams verschilt in beide regio's. Deze bevinding kan verklaard worden door het gegeven dat professionals dezelfde verwachtingen hebben van de taken en rollen van respectievelijk een coach en een manager, waaronder het ondersteunen van persoonlijke doelen en het stimuleren 
van teamontwikkeling. Deze verwachtingen passen zowel bij transformationeel als dienen leiderschap (Parolini e.a., 2009, in van Dierendonck, 2011). Een ander aspect dat van invloed kan zijn geweest op deze uitkomst is het gegeven dat de rol van de coach in Holland Rijnland gedurende de periode van dataverzameling voor veel professionals nog niet duidelijk was. Daarnaast vond in Den Haag een reorganisatie onder het management plaats, waardoor er veel wisselingen zijn geweest. De rol van manager en coach was dus in beide regio's gedurende de onderzoeksperiode in ontwikkeling. Tot slot kan het zo zijn dat de teams in Holland Rijnland en Den Haag in dezelfde 'levensfase' hebben gezeten (Morgeson e.a., 2010), waarbij een bepaalde leiderschapsstijl past.

In lijn met onze verwachting ervaren de professionals uit Den Haag de kwaliteit van regels en procedures hoger, maar beleven ze ook meer overbodige regels dan de professionals in Holland Rijnland. Leidinggevenden kunnen een belangrijke rol spelen in de manier waarop professionals regels en procedures ervaren. Een belangrijk aspect van leiderschap is namelijk het duiden en uitleggen van regels en procedures, en het toezien op de naleving ervan (Casimir, 2001). De manager in Den Haag biedt volgens de professionals kaders, creëert duidelijke voorwaarden en neemt standpunten in, terwijl de coach in Holland Rijnland meer ondersteunend is. Dit kan ertoe leiden dat professionals in Den Haag de kwaliteit van regels positiever waarderen, maar tegelijkertijd ook de regels en procedures als meer overbodig ervaren. De professionals uit de zelfsturende teams in Holland Rijnland zijn daarentegen zelf meer verantwoordelijk voor het duiden en naleven van regels en procedures. Dit kan ervoor zorgen dat professionals meer eigenaarschap ervaren, en regels en procedures minder snel als overbodig worden gezien. Professionals in Holland Rijnland ervaren wel meer onduidelijkheid rondom de regels en procedures, wat sommige professionals toeschrijven aan het ontbreken van een formeel leidinggevende. Het aantal regels en procedures kan effect hebben op het functioneren van een team en de kwaliteit van hulpverlening. Zo kunnen te veel en overbodige regels en procedures zorgen voor vertraging in het bieden van hulp (Friele e.a., 2018). Echter kunnen duidelijke regels en procedures ook voor zekerheid zorgen en zijn ze belangrijk voor de voorspelbaarheid en controleerbaarheid van het werk van de teams (Groeneveld, 2016). De afwezigheid van een formele manager lijkt dus samen te hangen met meer zelfmanagement, maar ook met meer onduidelijkheid en hinder omtrent regels en procedures.

De analyse van dit artikel is gebaseerd op 'mixed-methods', waarbij de resultaten van twee complementaire onderzoeken zijn gecombineerd. Het combineren van de kwantitatieve en kwalitatieve gegevens heeft geleid tot een meer volledig beeld dat recht doet aan een complexe praktijk. Het geschetste beeld in dit artikel moet geïnterpreteerd worden als een momentopname, aangezien beide onderzoeken gebaseerd zijn op de percepties en ervaringen van professionals tijdens een ontwikkelperiode waarin de Jeugd- (en Gezins)teams volop in beweging waren. Beperkingen van vragenlijstonderzoek, waaronder non-respons (immers: de helft van de teamleden heeft de vragenlijst niet ingevuld) en mogelijke sociale wenselijkheid in antwoorden, zijn van toepassing op dit onderzoek. Triangulatie van kwantitatieve en kwalitatieve data versterkt echter de betrouwbaarheid van onze resultaten. De interviews en vragenlijst zijn gedurende dezelfde periode in 
dezelfde doelgroep afgenomen. Hoewel dit vanuit twee verschillende onderzoeken is gebeurd, is er vooraf wel afstemming geweest wat betreft de vraagstelling in de vragenlijst en mogelijke aanvullingen die vanuit de eerste interviews naar voren kwamen.

Concluderend blijkt uit dit onderzoek dat de wijze van organisatie van de Jeugd(en Gezins)teams van invloed is op een aantal processen die ten grondslag liggen aan het teamfunctioneren, maar dat er ook veel overeenkomsten tussen beide regio's zijn. Gemeenten en jeugdhulporganisaties dienen zich bewust te zijn van de mogelijke effecten van organisatiewijze op het teamfunctioneren bij de doorontwikkeling van de Jeugd- (en Gezins)teams. Naast de organisatorische verschillen die in dit onderzoek bekeken zijn, bestaan er nog meer verschillen tussen Nederlandse gemeenten (Arum \& Van den Enden, 2018), die nader onderzocht kunnen worden. Omdat de komende jaren de jeugdhulp nog volop in ontwikkeling zal zijn, is het belangrijk om te monitoren of de verschillen en overeenkomsten tussen de regio's zullen veranderen en wat werkzame elementen van de organisatie van de Jeugd- (en Gezins)teams zijn. Het is waardevol om in toekomstig onderzoek niet alleen te kijken naar aspecten die ten grondslag liggen aan het teamfunctioneren, maar ook naar het daadwerkelijk functioneren van de teams en de kwaliteit van de hulpverlening. Vervolgonderzoek kan expliciet de relatie tussen teamfunctioneren en de kwaliteit van hulpverlening onderzoeken om zo te achterhalen welke aspecten van teamfunctioneren bijdragen aan betere hulpverlening voor jeugdigen en hun ouders. Het is daarbij van belang dat de onderzoeksresultaten goed vertaald worden naar de praktijk, zodat deze direct toegepast kunnen worden op de doorontwikkeling van bestaande teams of bij de organisatie van nieuwe teams.

\section{Literatuur}

Ancona, D.G. (1990). Outward bound: Strategies for team survival in an organization. Academy of Management Journal, 33 (2): 334-365.

Arum, S., \& Enden, T. van den (2018). Sociale (wijk)teams opnieuw uitgelicht. Movisie. www.movisie.nl/publicaties/sociale-wijkteams-opnieuw-uitgelicht, geraadpleegd op 13 juli 2018.

Basisdocument coöperatie Jeugd en Gezinsteams Holland Rijnland (2015). Versie 5, definitief.

Campion, M.A., \& Medsker, G.J. (1993). Relations between work groups characteristics and effectiveness: Implications for designing effective work groups. Personnel Psychology, 46: 823-850.

Casimir, G. (2001). Combinative aspects of leadership style: The ordering and temporal spacing of leadership behaviors. The Leadership Quarterly, 12: 245-278.

Dierendonck, D. van (2011). Servant leadership: A review and synthesis. Journal of management, 37 (4): 1228-1261.

Dinh, J.E., Lord, R.G., Gardner, W.L., Meuser, J.D., Liden, R.C., \& Hu, J. (2014). Leadership theory and research in the new millennium: Current theoretical trends and changing perspectives. The Leadership Quarterly, 25 (1): 36-62.

Dunphy, D., \& Bryant, B. (1996). Teams: Panaceas or prescriptions for improved performance. Human Relations, 49 (5), 677-699. 
Eerste Kamer der Staten-Generaal. Vergaderjaar 2013/14. Regels over de gemeentelijke verantwoordelijkheid voor preventie, ondersteuning, hulp en zorg aan jeugdigen en ouders bij opgroei- en opvoedingsproblemen, psychische problemen en stoornissen (Jeugdwet). 33648.

Eilander, J., Nooteboom, L. A., Mulder, E. A., Kuiper, C. H. Z. \& Vermeiren, R. R. J. M. (2017). Werkzame en belemmerende factoren van het werken in een Jeugd- (en Gezins)team: Visie van de professional. https://hollandrijnland.nl/wp-content/ uploads/2017/11/03b1-Rapport-Gezin-aan-Zet.pdf. Geraadpleegd op 22 juni 2019.

Evans, C.R., \& Dion, K.L. (1991). Group cohesion and performance: A meta-analysis. Small Group Research, 22 (2): 175-186.

Friele, R.D., Bruning, M.R., Bastiaanssen, I.L.W., Boer, R. de, Bucx, A.J.E.H., Groot, J.F. de, ... Hageraats, R. (2018). Eerste evaluatie Jeugdwet: Na de transitie nu de transformatie. Den Haag: ZonMw.

Groeneveld, S.M. (2016). Het belang van bureaucratie. Omgaan met ambivalentie in publiek management (interne publicatie). Leiden: Universiteit Leiden.

Groeneveld, S., \& Kuipers, B.S. (2014). Teamwork in the Public Cage: Antecedents of selfmanagement of teams in public organizations (Conference paper prepared for the Academy of Management 2014 Annual Meeting).

Hoek, M. van der, Groeneveld, S., \& Kuipers, B. (2018). Goal Setting in Teams: Goal Clarity and Team Performance in the Public Sector. Review of Public Personnel Administration, 38 (4): $472-493$.

Inkoopplan Jeugdhulp 2016 (2015). Lokale uitgangspunten voor de jeugdhulp in 2016. Gemeente Den Haag.

Jensen, U.T., Andersen, L.B., Bro, L.L., Bøllingtoft, A., Eriksen, T.L.M., Holten, A.L., ... Würtz, A. (2019). Conceptualizing and measuring transformational and transactional leadership. Administration \& Society, 51 (1): 3-33.

Knies, E., Jacobsen, C., \& Tummers, L.G. (2016). Leadership and organizational performance: State of the art and research agenda. In: J. Storey, J.L. Denis, J. Hartley \& P. 't Hart (red.), Routledge Companion to Leadership. Londen: Routledge, 404-418.

Knippenberg, D. van, Dreu, C.K.W. de, \& Homan, A.C. (2004). Work group diversity and group performance: An integrative model and research agenda. Journal of Applied Psychology, 89 (6): 1008-1022.

Kozlowski, S.W., \& Ilgen, D.R. (2006). Enhancing the effectiveness of work groups and teams. Psychological Science in the Public Interest, 7 (3): 77-124.

Kuipers, B.S., \& Groeneveld, S.M. (2014). De kracht van high performance teams: zes ingrediënten voor excellent presteren in de publieke sector. Den Haag: Mediawerf.

Kuipers, B.S., \& Stoker, J.I. (2009). Development and performance of self-managing work teams: a theoretical and empirical examination. The International Journal of Human Resource Management, 20 (2): 399-419.

Lipsky, M. (1980 [2010]). Street-level Bureaucracy. Dilemmas of the Individual in Public Services. New York: Russell Sage Foundation.

Mesmer-Magnus, J.R., \& DeChurch, L.A. (2009). Information sharing and team performance: A meta-analysis. Journal of Applied Psychology, 94 (2): 535-546.

Morgeson, F.P., DeRue, D.S., \& Karam, E.P. (2010). Leadership in teams: A functional approach to understanding leadership structures and processes. Journal of Management, 36 (1): 5-39.

Omschrijving dienstverlening Jeugd en Gezinsteam, Holland Rijnland (2015). Definitief. https://hollandrijnland.nl/wpcontent/uploads/2016/11/03e-Omschrijvingdienstverlening-Jeugd-en-gezinsteam.pdf, geraadpleegd op 16 mei 2017. 
Parolini, J., Patterson, K., \& Winston, B. (2009). Distinguishing between transformational and servant leadership. Leadership \& Organization Development Journal, 30 (3): 274-291.

Pope C., Ziebland S., \& Mays, N. (2000). Qualitative research in healthcare: Analysing qualitative data. British Medical Journal, 320: 114-116.

Poulton, B.C., \& West, M.A. (1999). The determinants of effectiveness in primary health care teams. Journal of Interprofessional Care, 13 (1): 7-8.

Rijksoverheid \& VNG (2014). Handreiking Samenwerken binnen (jeugd)wijkteams: Over verantwoordelijkheid en aansprakelijkheid bij calamiteiten. https://vng.nl//files/vng/ 20141211_handreiking_samenwerking_in_jeugdwijkteams.pdf, geraadpleegd op 18 juli 2018.

Steijn, B., \& Voet, J. van der (2017). Relational job characteristics and job satisfaction of public sector employees: When prosocial motivation and red tape collide. Public Administration: 1-17.

Steijn, B., Voet, J. van der, \& Huizenga, S. (2017). Teamkenmerken en gepercipieerde prestaties van wijkteams. http://hdl.handle.net/1765/99022, geraadpleegd op 18 juli 2018.

Tashakorri, A., \& Teddlie, Ch. (1998). Mixed methodology. Combining qualitative and quantitative approaches. Thousand Oaks: Sage.

Tjosvold, D., Tang, M.M.L., \& West, M. (2004). Reflexivity for team innovation in China: the contribution of goal interdependence. Group \& Organization Management, 29 (5): 540-559.

Werkzame en belemmerende factoren van het werken in een Jeugd- (en Gezins)team: visie van de professional. https://hollandrijnland.nl/wp-content/uploads/2017/11/03b1Rapport-Gezin-aan-Zet.pdf, geraadpleegd op 22 juni 2019.

Wisdom, J.P., Cavaleri, M.A., Onwuegbuzie, A.J., \& Green, C.A. (2012). Methodological reporting in qualitative, quantitative, and mixed methods health services research articles. Health Services Research, 47 (2): 721-745.

Zaccaro, S.J., Heinen, B., \& Shuffler, M. (2009). Team leadership and team effectiveness. In: E. Salas, G.F. Goodwin \& C.S. Burke, Team effectiveness in complex organizations: Cross-disciplinary perspectives and approaches. New York: Routledge, 83-111. 